IZA DP No. 9654

Crowding Out in the Labour Market:

Do Employers Lend a Hand?

Dieter Verhaest

Elene Bogaert Jeroen Dereymaeker Laura Mestdagh

Stijn Baert

January 2016 


\title{
Crowding Out in the Labour Market: Do Employers Lend a Hand?
}

\author{
Dieter Verhaest \\ KU Leuven (Brussels Campus) \\ and Ghent University \\ Elene Bogaert \\ Ghent University
}

\author{
Laura Mestdagh \\ KU Leuven
}

\section{Stijn Baert}

Ghent University, University of Antwerp, Université catholique de Louvain and IZA

\section{Jeroen Dereymaeker \\ KU Leuven}

\author{
Discussion Paper No. 9654 \\ January 2016
}

IZA

P.O. Box 7240
53072 Bonn
Germany

Phone: +49-228-3894-0

Fax: +49-228-3894-180

E-mail: iza@iza.org

\begin{abstract}
Any opinions expressed here are those of the author(s) and not those of IZA. Research published in this series may include views on policy, but the institute itself takes no institutional policy positions. The IZA research network is committed to the IZA Guiding Principles of Research Integrity.

The Institute for the Study of Labor (IZA) in Bonn is a local and virtual international research center and a place of communication between science, politics and business. IZA is an independent nonprofit organization supported by Deutsche Post Foundation. The center is associated with the University of Bonn and offers a stimulating research environment through its international network, workshops and conferences, data service, project support, research visits and doctoral program. IZA engages in (i) original and internationally competitive research in all fields of labor economics, (ii) development of policy concepts, and (iii) dissemination of research results and concepts to the interested public.
\end{abstract}

IZA Discussion Papers often represent preliminary work and are circulated to encourage discussion. Citation of such a paper should account for its provisional character. A revised version may be available directly from the author. 


\section{ABSTRACT}

\section{Crowding Out in the Labour Market: Do Employers Lend a Hand?*}

We test the basic assumption underlying the job competition and crowding out hypothesis: that employers always prefer higher educated to lower educated individuals. To this end, we conduct a randomised field experiment in which duos of fictitious applications by bachelor and master graduates are sent to real vacancies requiring only a bachelor degree. Our design allows to look at whether employers' preferences for overqualified versus adequately qualified applicants depend on the demand and supply context, sectoral activity and type of organisation, and characteristics of the posted vacancy. For the overall sample, we find that master graduates are $19 \%$ more likely to be directly invited for a job interview. Nonetheless, we conclude that eventual crowding out of bachelor graduates as a consequence of this selection policy is unlikely to be large since the advantage for master graduates is particularly observed for jobs with high overall invitation rates.

JEL Classification: I21, J24, M51

Keywords: job competition, recruitment, hiring, youth labour market, mismatch, underemployment, overqualification, field experiments

Corresponding author:

Dieter Verhaest

KU Leuven (Brussels Campus)

Warmoesberg 26

1000 Brussel

Belgium

E-mail: Dieter.Verhaest@kuleuven.be

\footnotetext{
${ }^{*}$ We thank Nick Drydakis and the participants of the 2015 workshop on Transitions in Youth in Brno for their valuable comments on an earlier draft of this paper.
} 


\section{Introduction}

It is well-established that many young workers are employed in jobs that require less education than is needed for their job - i.e. they are "underemployed" or "overqualified" (Hartog, 2000; McGuinness, 2006). One of the possible explanations for this finding is provided by a combination of labour market imbalances and processes of downward wage rigidity. Reder (1955) already claimed that, when applicants are plentiful and wages are downwardly rigid, employers increase hiring standards. Later contributions by Hall (1974), Thurow (1975) and Okun (1981) put forward similar arguments. Thurow (1975), for instance, outlined a theory in which wages are tied to jobs and job seekers compete for these jobs on the basis of their expected trainability. If education provides a reliable signal of trainability, higher educated job seekers will be in front of the job queue. Hence, when job opportunities are scarce and higher educated labour market entrants apply for jobs requiring less education, adequately qualified job seekers will be crowded out to the next lower level or even to unemployment.

The job competition and crowding out hypothesis has been tested in various ways in the literature. Consistent with cyclical quality adjustments, several studies have found that occupational downgrading and the likelihood to be overqualified is countercyclical (Teulings and Koopmanschap, 1989; Devereux, 2002; 2004; Pollman-Schult, 2005; Büttner et al., 2010). van Ours and Ridder (1995) investigated the job competition hypothesis more directly by assessing whether the flow of filled vacancies within an educational segment is affected by the level of unemployment at higher skill segments. They found evidence for job competition, but only between workers with a higher vocational and an academic degree. Gautier et al. (2002) compared the in- and outflow within jobs between two downswing and two upswing years. They concluded that the evidence on cyclical crowding out is thin since any change in the educational composition within jobs taking place during the recession years was found to result from the outflow of lower educated workers rather than from the inflow of higher educated workers. Finally, in line with the crowding-out hypothesis, Gesthuizen and Wolbers (2010) found an increase in the oversupply of high skilled workers to reduce the employment chances of low skilled unemployed individuals.

While some of the aforementioned studies provide partial evidence for the claim that labour market opportunities of lower educated individuals may be negatively affected by the job search behaviour of higher educated individuals, they do not test the basic assumption of the job competition theory: that employers always prefer higher educated to lower educated individuals. From a theoretical point of view, along with the argument of higher trainability as advanced by Thurow (1975), several other arguments can be put 
forward why employers may prefer overqualified workers. First of all, their surplus of education may not only signal higher trainability, but also higher innate ability (Spence, 1973). Further, even if not fully utilised, the surplus of education may not be fully useless and still generate a small but significant effect on productivity. However, other arguments may make employers rather reluctant to hire overqualified workers. Overqualified workers are often found to be less satisfied with their jobs than their co-workers (Korpi and Tåhlin, 2009; Verhaest and Omey, 2009), probably resulting in lower performance than potentially can be achieved. Moreover, a few studies also found them to engage more often in on-thejob search and quitting behaviour than their colleagues (Tsang et al., 1991; Robst, 1995), thus resulting in lost recruitment and training costs. Further, by being prepared to apply for jobs below their level of education and not managing to find an adequate job, overqualified job seekers may just as well send negative signals towards employers (McCormick, 1990). Finally, as opposed to what was assumed by Thurow (1975), it is generally found that overqualified workers earn a small but significant wage bonus in comparison to their adequately but lower qualified counterparts (Hartog, 2000; Rubb, 2003; Korpi and Tåhlin, 2009). Hence, even if overqualified workers are more productive, this has to be traded off against the eventual wage bonus that has to be paid to them.

Only a few studies, all relying on experimental methods, have already investigated the hiring decisions of employers regarding overqualified and adequately qualified applicants in an empirical way. van Beek et al. (1997) conducted a stated preference experiment in which Dutch employers had to select job applicants with different attributes for lower-skilled jobs. While underqualified job seekers were found to be penalised in the selection process, the overqualified ones were not found to be treated differently from those being adequately qualified. More recently, Humburg and van der Velden (2015) conducted a similar experiment in nine European countries. Recruiters were asked to select university graduates for a typical junior position. On average, those with a $\mathrm{PhD}$ were found to have lower chances to be recruited while bachelor and master graduates were treated equally. However, it turned out that these results hided substantial heterogeneity, with recruiters in the UK having a preference for bachelor graduates and recruiters in several other countries, such as France and Germany, having a preference for master graduates.

In this paper, we provide further experimental evidence regarding employer preferences for overqualified versus adequately qualified applicants. We contribute in three main ways to the literature. First, rather than relying on a stated preference experiment, we are the first in this literature to leave the lab for the field. More concretely, we conduct a field experiment by sending fictitious applications of overqualified and adequately qualified graduates to real vacancies. Even if stated choice experiments are well-spread in social sciences, there is substantial discussion in the literature about the extent to which 
hypothetical choices reflect real choices. At least, research indicates that even small differences in stated choice designs may generate substantial differences in performance (e.g., Neill et al., 1994; Hainmueller et al., 2015). By conducting a field experiment, we overcome this problem, i.e. we investigate real hiring behaviour.

As a second contribution, we investigate more profoundly to what extent hiring behaviour regarding overqualified and adequately qualified applicants depends on the specific labour market context. We hypothesise that overqualified applicants are more likely to be treated favourably when vacancies are easier to fill. When labour market tightness is low, recruiters can be more selective (cf. Baert et al., 2015). Further, the risk of reduced productivity and early job quitting by overqualified workers may be assessed to be lower when overqualified workers have less outside options. Moreover, this lack of outside options reduces the bargaining power of overqualified workers and may thus also reduce the wage bonus that has to be paid to them. The opposite may be true when vacancies are difficult to fill and job opportunities are abundant, with employers even being suspicious about individuals nevertheless being prepared to apply for jobs for which they are overqualified.

Finally, we also look at whether recruitment behaviour differs across different types of jobs and organisations. The productivity of overqualified workers is likely to differ across these dimensions. Mahy et al. (2015) for instance claim that overqualified workers are relatively more productive in high-tech jobs since their higher education may reduce the loss in productivity resulting from the introduction of new technologies. van der Meer and Wielers (1996) then again claim overqualified workers to be preferred when output is hard to measure, such as in the professional service sector. In this case, the qualifications of the employees might serve as a legitimation to the clients of the quality of the offered service. Apart from differences across types of activities, also differences between public and private organisations may be expected. Public organisations often have to adhere to strict recruitment rules, which may limit their ability to favour overqualified workers. Private firms, on the other hand, are more flexible to adapt their technologies to changes in labour supply and also have more opportunities to offer overqualified workers wage premiums and promotion opportunities (Dolton and Vignoles, 2000). We identify these potentially heterogeneous treatment effects across jobs and sectors by sending out our fictitious applications to vacancies for a strategically chosen set of different occupations.

We conduct our field experiment in the Belgian (Flemish) graduate labour market. We send out 1024 fictitious male job applications to real vacancies. These vacancies are for jobs requiring a bachelor degree and are situated within a broad range of fields of study. The applicants only differ by their highest obtained degree. One graduated a few months earlier with a bachelor degree, another one with a master degree. By monitoring the subsequent 
call-back from the employer side, the preference for a graduate with a particular degree is identified.

\section{Experiment}

\subsection{Correspondence Testing}

For our analysis, we rely on correspondence testing as initiated by Bertrand and Mullainathan (2004). Within this experimental framework, pairs of fictitious job applications, differing only by the attribute that is tested, are sent to real vacant jobs. By registering the subsequent call-back, unequal treatment based on this attribute can be identified. Since all the recruiter's decision making information is under control of the researcher, selection on unobservables is not an issue (Riach and Rich, 2002; Pager, 2007). While originally implemented to test for racial discrimination, correspondence experiments were also used to study the impact of previous labour market trajectory characteristics such as spells of unemployment (Eriksson and Rooth, 2014; Kroft et al., 2013) or experience as an overqualified or underemployed worker (Baert and Verhaest, 2014). However, only a few recent studies already used this framework to test for the signalling value of education related outcomes. As in our study, Nunley et al. (Forthcoming) and Drydakis (2015) sent applications to bachelor level jobs. However, focussing on college major, the role of internships and university reputation, they did not include (overqualified) master applicants in their design.

\subsection{Experimental Identities}

In line with the general correspondence testing framework, we sent duos of fictitious applications to real vacancies for starter jobs in Flanders, the Northern part of Belgium. One application was for a male graduate having obtained a few months earlier a bachelor degree (named the "bachelor applicant" hereafter) and another one for a male graduate having obtained a master degree at the same moment (named the "master applicant" hereafter). Both had completed their final degree in June 2014 and had become unemployed afterwards.

In Flanders, two different types of bachelor degrees can be obtained: a so-called professional bachelor degree, awarded by colleges ("hogescholen" in Dutch) and a so-called academic bachelor degree awarded by traditional universities. While the professional bachelor program is intended to prepare directly for the labour market, the academic 
bachelor program rather prepares for entrance into a master program. Master degrees are obtained by following one or more years of academic education and are only awarded by universities. Notwithstanding the fact that most of the master students enter their (master) program after having obtained an academic bachelor degree, a substantial number of students with a professional bachelor degree also proceed in a (related) master program. To be eligible for a master program, these students first have to follow a one-year so-called "bridging" program.

Given that an academic bachelor program intends to prepare for a master program rather than for the labour market, only a small minority enters the labour market immediately after having obtained such an academic bachelor degree. ${ }^{1}$ Hence, we assumed the bachelor applicant in our study to have obtained his degree in college. Further, to maximise the comparability of the two applications, the master applicant in our study was assumed to have obtained the same bachelor degree at the same college two years earlier, after which he proceeded subsequently with a bridging and (one-year) master program. ${ }^{2}$

To further warrant comparability, two additional conditions were put forward regarding the college and university at which the applicants obtained their degree(s). First of all, we assumed both the bachelor and master degree to be obtained at a college and university that is part of the same so-called "university association". In Flanders, each college is obliged to be associated with one university. Such an association involves collaboration both in terms of education and research. Moreover, the university with which a college is associated is usually mentioned in all the college's official communication (e.g., in the college's logo), resulting in a high visibility to the broader public. Hence, there is unlikely to be a reputation mismatch between the colleges and the university that are part of the same association. Second, only colleges were selected that are located in the same urban agglomeration as the one of the university and the home residence of the fictitious applicant. Hence, the applications could not signal any difference in the applicants' attitude towards geographical mobility.

Given the aforementioned prerequisites, all applicants were assumed to have obtained their degree(s) at Ghent University or colleges associated with Ghent University and only at campuses located in the Ghent urban agglomeration. In terms of the number of students

\footnotetext{
${ }^{1}$ According to the Flemish Public Employment Service (VDAB, 2015), only 1,004 (3.1\%) of all graduates entering the labour market in 2013 had an academic bachelor degree as opposed to $16,823(51.4 \%)$ graduates with a professional bachelor degree and 14,864 (45.5\%) graduates with an academic master degree.

${ }^{2}$ During the academic year 2013-2014, 7,187 students participated in a bridging program at a Flemish university; during the same year, 20,214 students were inscribed for the first time in an academic bachelor program (Ministerie van Onderwijs en Vorming, 2015).
} 
in higher education, Ghent is ranked first among all Flemish cities (the city of Brussels excluded $^{3}$ and the Ghent University association is ranked second among all associations (five in total). In terms of population, Ghent is the second biggest city of Flanders (the city of Brussels excluded). Moreover, although Ghent is located at the Western side of the geographical centre of the region, the largest part of the Flemish territory (including Antwerp and Bruges, respectively the biggest and third biggest city of Flanders) as well as Brussels-Capital Region ${ }^{4}$ can be reached within a reasonable travel time of one hour by car or public transport. This allows to apply for a majority of the vacant jobs being available for bachelor graduates in Flanders and Brussels-Capital Region.

For the fictitious applications sent, we selected bachelor programs conditional on the following four prerequisites: (A) such a program is being offered by one of the colleges associated with Ghent University and located in the Ghent agglomeration, (B) Ghent University offers a one-year master program that clearly matches in terms of content with this bachelor program offered by the college, (C) Ghent University offers a one-year bridging program allowing to enter the master program after having obtained this bachelor program, and (D) more than a few students participate in the concerned bridging program. The latter condition was added to ensure that employers perceive the bridging program not to be an uncommon way to obtain a particular master degree. These four conditions delivered a selection of bachelor and related master programs in the following five different domains: (1) Business and Communication Science, (2) Industrial Science and Engineering, (3) (Applied) Computer Science and Engineering, (4) Health Care and (5) Social Work and Pedagogy. ${ }^{5}$ This broad range of domains guarantees that our outcomes are not specific for one particular field or occupational group. Moreover, it allows to differentiate between segments of the labour market that differ in the extent to which vacancies are easy or difficult to fill and between different sectors and organisations (cf. infra).

We assume that both applicants obtained their final degree during the same academic year (academic year 2013-2014) and did not experience any delay during their educational career. As a consequence, the master applicant is two years older (23 years) than the bachelor graduate (21 years) in our experiment. Alternative options, aimed to have applicants of the same age, would have been to add years of delay in education or additional years of unemployment in the resume of the bachelor applicant. However, two years of

\footnotetext{
${ }^{3}$ A number of Flemish higher education institutions are located in the bilingual Brussels area. While Brussels ranks first in terms of the number of students in Belgium as a whole, this is largely due to participation in programs offered at colleges and universities of the French-speaking community.

${ }^{4}$ Belgium is a federal state consisting of the following three regions: Brussels-Capital Region, Flanders and Wallonia.

${ }^{5}$ A complete list of all programs that are included in each domain can be found in Appendix A (Table A1).
} 
unemployment or delay in education may generate strong negative signals towards employers. Hence, this would largely complicate the interpretation of the results of our experiment. While also age may matter as a selection criterion, the impact of an age of 21 instead of 23 is likely to be much smaller. Moreover, being older at labour market entry can be considered to be an inherent implication of the decision to obtain an additional master degree. Hence, when assessing the labour market effects of this decision, this age effect should be taken into account as well. We will turn back to this issue in the discussion section.

\subsection{Resume Templates}

For each of the combinations of bachelor and master programs that were selected, we constructed two different types of resumes and motivation letters (type A versus type B) matching the general requirements of starter jobs for individuals graduated from such a program. At the level of the program, all resumes and motivation letters were identical concerning all crucial characteristics. However, to avoid detection, type A resumes and cover letters differed from type B ones concerning lay-out and inessential particularities. All applicants were single males born and living in the Ghent urban agglomeration and had graduated from a high school with a standard reputation. Further, we added the following characteristics to the resumes: a common Flemish sounding name, an address with an existing street name but a non-existing house number in a middle-class neighbourhood, a mobile phone number, an email address from a commercial provider, a birth date, the Belgian nationality, comparable language and computer skills, ${ }^{6}$ a driving licence, one or two sports activities, one or two practised socio-cultural activities and experience in two different student jobs without much relevance for the bachelor level jobs (e.g., student work as a shop assistant). Finally, each type of resume also mentioned a few similar subjectively assessed personal qualities (e.g., the applicant claimed that he was a flexible and communicative person). The motivation letters mentioned the job title for which one was applying, expressed one's interest in the job and highlighted (in a different wording) a number of aspects also mentioned in the resume.

For both types of resumes and cover letters, two versions were created only differing in whether it concerned a bachelor applicant or a master applicant. In total, we thus created four different resumes and cover letters for each program (type A-bachelor, type A-master,

${ }^{6}$ For most of the programs, these include standard computer skills such as the ability to work with Microsoft Office software. For particular programs, such as programs in computer science or electronics, also more specialised computer skills were added for both application types. 
type B-bachelor and type B-master). In the motivation letter, two sentences were added revealing one's final degree and its main characteristics. ${ }^{7}$ In the resume, we added information on the full higher education career, consisting of the year(s) of participation, the name(s) of the college (and university), and the name(s) of the program(s). To avoid detection, slightly different wordings were used for resumes of type A and those of type B. The resumes and motivation letters are available upon request.

\subsection{Selected Job Openings}

Our experiment was conducted between November 2014 and April 2015. During this period, we selected and applied for vacancies from the online database of the Flemish Public Employment Agency. We confined ourselves to vacancies for starter jobs with a bachelor degree in one of the selected programs as minimum requirement to be hired. ${ }^{8}$ To avoid selecting master level jobs for which additional work experience could serve as a substitute for a master degree, we further restricted our experiment to vacancies for which work experience was not a necessary prerequisite. ${ }^{9}$ Further, we only applied for jobs in Flanders and Brussels-Capital Region located in districts within a reasonable distance from Ghent (maximum one hour travelling distance by car). Finally, we selected no more than one job from the same employer or organisation to avoid detection. In total, we were able to select 512 vacancies. The division across educational domains was as follows: 152 vacancies were for graduates with a degree in Business and Communication Science, 90 vacancies for graduates in Industrial Sciences and Engineering, 52 vacancies for graduates in (Applied)

${ }^{7}$ As an example, we provide the sentences for graduates from programs in accountancy and taxation (domain business and communication science). For the bachelor version of the type A motivation letter we mentioned: "As a recently graduated bachelor in business management, with a specialisation in accountancy and taxation, I find this job an attractive challenge. In my bachelor education at college, I acquired valuable and relevant knowledge that will be useful in a job as [job title as mentioned in vacancy]." For the bachelor version of the type B motivation letter we mentioned: "In June, I obtained my diploma of bachelor in Business Management, option Accountancy-Taxation. This professional program allows me to put relevant knowledge into practice." For the master version of the type A motivation letter: "As a recently graduated master in business administration, with a specialisation in accountancy and taxation, I find this job an attractive challenge. Both in my bachelor education at college and my master education at university, I acquired valuable and relevant knowledge that will be useful in a job as [job title as mentioned in vacancy]." Lastly, for the master version of the type B motivation letter: "After first having participated in a professional bachelor program, I obtained in June my diploma of master in Business Administration, option Accountancy and Taxation. This combination allows me to connect practice with the most recent scientific knowledge."

${ }^{8}$ Also vacancies that explicitly mentioned to be open to both bachelor and master degree graduates were selected since the bachelor degree is the minimum requirement to be selected (cf. infra).

${ }^{9}$ The search interface of the Public Employment Agency allowed to select vacancies for which work experience was not a prerequisite to apply for the job. Nonetheless, many of these vacancies indicated in the description that work experience would be considered to be a plus. These vacancies were selected unless it was explicitly mentioned that work experience was a necessary prerequisite. 
Computer Science and Engineering, 120 vacancies for graduates in Health Care and 92 vacancies for graduates in Social Work and Pedagogy.

Given that vacancies were selected with a bachelor degree as minimum requirement to be hired, the bachelor (master) applicant was thus adequately qualified (overqualified) for the job. We deliberately chose the term "overqualification" instead of "overeducation" since we rely on minimum hiring requirements. With overeducation, we rather refer to a discrepancy between one's education and the education required to perform the job (cf. Hartog, 2000; Dolton and Silles, 2003). While it is not unusual to measure overeducation relying on hiring requirements as well, a number of studies have shown that the minimal required level to get a job not always coincides with the level required to do this job (Dolton and Silles, 2003; Verhaest and Omey, 2006). This may be attributed to two different factors. One reason may be that employers adapt the hiring requirements specified in the vacancy in response to an oversupply or undersupply of job seekers. Another explanation may be that hiring requirements adapt with some delay to structural changes in the skills that are required. A recent study by Hershbein and Kahn (2015) suggests the latter explanation to be dominant. They found a substantial increase in hiring requirements during the great recession without any reversion afterwards. Hence, it seems that, during recessions, employers take the opportunity to restructure their workforce towards the skill needs resulting from technological changes. Given that our experiment was conducted in the aftermath of the great recession, this interpretation would imply that hiring requirements of the selected job postings largely aligned with education required for doing the job. If so, our results can also be interpreted in terms of differences in hiring chances between adequately educated and overeducated applicants for vacant jobs.

\subsection{Application Procedure and Call-Back Registration}

To each suitable vacancy, two applications were sent, one for a bachelor applicant and another one for a master applicant, thus resulting in a total of 1024 applications. To avoid detection, one type A application was always combined with one type B application. This results in two possible combinations (type A-bachelor combined with type B-master or type B-bachelor combined with type A-master). We balanced the use of these combinations within each educational domain. Hence, eventual differences in outcomes between bachelor and master applicants cannot be attributed to any differences in details between type A and type $\mathrm{B}$ resumes and motivation letters. The aforementioned combinations were sent to employers each time with one or two working days in between. To avoid any order effects, we alternated regarding the application (bachelor versus master and type A versus type B) that was sent first. We always applied relying on the resume and motivation letter 
mentioning the bachelor (and linked master) program that matched the one requested by the employer. ${ }^{10}$

We collected call-backs from the employers by means of email or mobile phone voicemail. The exact content of the responses was registered for each call-back and is available upon request. Right after collecting a positive reaction, we replied to the employers by means of an email in which the offer was declined. This should have minimised any inconvenience to the firm. Eventual responses received beyond 30 days after sending out the resume were always considered to be negative.

We apply two definitions of positive reactions in our analysis: positive call-back sensu stricto and positive call-back sensu lato. With a positive call-back sensu stricto, we mean that the applicant got an invitation for a face-to-face job interview. With positive call-back sensu lato, we also include all other positive (interested) reactions such as the request to call back the employer or to provide more information about particular aspects of the resume or motivation letter.

\subsection{Variation in Characteristics of the Vacancies}

In our analysis, we subdivide the call-back registered depending on the characteristics of the tested vacancies. A first series of these vacancy characteristics are related to the content of the job and the type of the firm. First, we subdivide the sample on the basis of the educational domain (see Section 2.2) that is required for the job. Second, we look at differences across sectors of activity. To retrieve the sector of the firm, we relied on the information in the vacancy regarding the name and address of the recruiting firm. NACE sectoral codes of the main activities for each firm were obtained from the website of the ministry of economic affairs based on this name and address. For our analysis, we grouped these codes into the following five sectoral domains: (1) Manufacturing, Energy and Construction, (2) Wholesale, Retail, Catering, Transport and Communication, (3) Finance, Insurance and Intellectual Services, (4) Public Administration, Education, Culture and Membership Organisations, and (5) Health Care and Social Work Activities. ${ }^{11}$ Third, we differentiate between private and public organisations. Public organisations are defined as

\footnotetext{
${ }^{10}$ In the case more than one of the selected programs were mentioned or in the case no details were provided regarding the requested specialisation (e.g., if the vacancy specified that a "bachelor in nursing" was required without mentioning further details), we selected the one matching most closely the job title.

${ }^{11}$ Since for some firms more than one main activity was mentioned, some of them are categorised in more than one sectoral domain. In case more than three main activities were mentioned, we selected only the three most important activities. Activities of minor importance to the firm were not taken into account. For this assessment, we also relied on external sources such as the webpage of the firm.
} 
organisations either being directly controlled by a political authority or being predominantly publicly financed. ${ }^{12}$

Further, we will also look at heterogeneous treatment effects by the importance of the demand and supply conditions by differentiating between bottleneck vacancies and other vacancies. For this, we matched each vacancy with an occupation in the occupational classification of the Flemish Public Employment Agency. For each occupation, each year this agency assesses whether there are quantitative bottlenecks, qualitative bottlenecks or no bottlenecks. Quantitative bottleneck occupations are occupations with difficulties to fill vacancies because of pure quantitative shortages of applicants. Qualitative bottleneck occupations are occupations with difficulties to fill vacancies not just because a lack of applicants but because the "quality" (i.e. skills) of the applicants is not sufficient. As mentioned in the introduction, we expect the hiring chances of master graduates to be relatively less favourable in the case of quantitative bottlenecks. Regarding qualitative bottlenecks, however, we expect them to have relatively more favourable invitation rates since their additional degree may reduce the problem of insufficient skills.

Finally, we split up the experimental data depending on a number of characteristics of the vacancy that reveal some more information about the specific aspirations of the employer in the context of the posted job. First, even if we only selected vacancies for which work experience was not a prerequisite to apply, it was sometimes mentioned that some work experience was nonetheless a plus point. We might expect master degrees to have an advantage for these vacancies since a master degree may act as a substitute for lack of work experience. Second, part of the vacancies explicitly mentioned that the job was open to both bachelor and master graduates. Evidently, we expect the invitation rates for master (bachelor) graduates to be relatively more (less) favourable for these vacancies than for vacancies only mentioning a bachelor degree as requirement.

\subsection{Research Limitations}

We end this method section with a number of limitations related to our experimental design that were not already mentioned before. For an extended discussion about the ethical aspects of our method, we refer to Riach and Rich (2004).

A major limitation of our research design is its focus on a rather specific labour market outcome, i.e. the invitation for a first job interview. Since we confine ourselves to the first

\footnotetext{
${ }^{12}$ Our motivation to categorise the latter as belonging to the public sector is that they are likely to be, to a large extent, "constrained by public authority" (cf. Bozeman, 1987).
} 
stage of the recruitment process, our analysis does not deliver direct information about differences in job finding rates. Nonetheless, research indicated that invitations for first job interviews are a decisive factor for chances to be finally hired (Cédiey et al., 2008). Moreover, alternatives to overcome this problem, such as audit tests in which actors participate in job invitations, are costly and have been criticised for several (methodological) reasons (Heckman and Siegelman, 1993; Riach and Rich, 2002). For instance, actors may consciously or unconsciously adjust their behaviour according to their own beliefs regarding determinants of labour market success.

Related to this first limitation, we only focus on the first job of graduates. As a consequence, our results cannot simply be translated to later stages in the career. It can be expected that differences in educational careers are less important for older workers than for younger ones, because differences in previous labour market careers may matter more for experienced job candidates. Nonetheless, bad labour starts are consistently found to have a persistent impact on future labour market outcomes (e.g., Gregg, 2001; Mroz and Savage, 2006). As such, focussing on first jobs is defendable. Moreover, this focus also has a main practical advantage when conducting correspondence experiments. When designing resumes for older workers, much more information has to be taken into account and a much larger diversity in profiles is possible. This complicates the development of resumes that are equivalent and also reduces the generalisability of the results.

Finally, even if the generalisability of the conclusions may be less problematic when focusing on young workers than on older ones, full representativity cannot be achieved. We only focus on male applicants with a degree within a strict set of domains and only apply for a particular set of jobs posted at the Flemish Public Employment Agency. This problem is inherent to the experimental framework and is traded-off against the benefit of resolving the endogeneity of educational choices with respect to labour market success. Nonetheless, as mentioned before, we tried to minimise the problem by focussing on a broad range of programs preparing for largely different occupations and sectors of employment.

\section{Results}

\subsection{Bivariate Analysis}

Table 1 and 2 report the positive call-back rates for both types of graduates, respectively 
defined in the strict sense and the broad sense. ${ }^{13}$ On the basis of the overall sample (Table 1 , row 1 ), we find that master graduates get $20.5 \%$ immediate invitations for a job interview compared to only $17.2 \%$ invitations for bachelor graduates. The ratio of these call-back rates is 1.193 indicating that master candidates get $19.3 \%$ more invitations for a job interview (column (4)). This call-back ratio is significantly different from 1 at the $5 \%$ level. When defined in the broad sense, call-back rates are $38.3 \%$ and $34.4 \%$ for master and bachelor graduates respectively, resulting in a call-back ratio of 1.114 (Table 2). Also this ratio is statistically significantly different from 1 . On the basis of the overall sample, we can thus safely conclude that master graduates are treated more favourable than bachelors for jobs requiring a bachelor degree. In other words, these overall statistics seem to support a role for employer preferences underlying job competition and crowding out in the labour market.

\section{$<$ Table 1 about here $>$}

Next, we split up the overall sample depending on the educational domain required for the job (row 2). Conversely to what is found for the overall sample, we do find a lower callback rate for masters than for bachelors in the case of Business and Communication Science. However, the call-back ratio is not statistically significantly different from 1. For the other required educational domains, call-back rates are always higher for master graduates than for bachelor graduates. For Computer Science and Engineering these differences are statistically significant at the $10 \%$ significance level relying on both definitions of positive call-back. In the case of Industrial Science and Engineering, only the sensu stricto definition reveals significant differences. For Health Care and Social Work and Pedagogy, conversely, only the call-back ratio sensu lato is significantly different from 1.

\section{$<$ Table 2 about here $>$}

Also across sectors and types of organisations (row 3 and 4), we observe higher call-back rates for master graduates in comparison to bachelor graduates. However, the call-back ratios are not statistically different from 1 for the Wholesale, Retail, Catering, Transport and Communication sectors and for the Public Administration, Education, Culture and Membership Organisations sectors. The Health Care and Social Work Activities sector then again delivers a significantly higher positive call-back rate for the master graduates than for bachelor graduates on the basis of both definitions. For the Manufacturing, Energy and Construction sectors and for the Finance, Insurance and Intellectual Services sectors, outcomes are not consistent across the two definitions. While both sectors experience significantly higher job invitation rates for masters than for bachelors, no evidence is found

\footnotetext{
${ }^{13}$ Frequencies are reported in Appendix A (Table A2 and A3).
} 
on statistical significant differences in overall positive call-back rates. Finally, also the outcomes across public and private organisations are not consistent. In line with expectations, we do find significantly higher job invitation rates for masters when applying for jobs at private organisations but not when applying for jobs at public organisations. However, the opposite conclusion is suggested when relying on the positive call-back sensu lato indicator.

Next, we look at whether recruitment behaviour depends on the bottleneck status of the vacancy. In the case of quantitative bottleneck vacancies, master graduates are found to be $28.3 \%$ more likely to be invited for a job interview than bachelor graduates (Table 1 , column 4). The overall positive call-back is $23.7 \%$ higher for master than for bachelor applicants (Table 2, column 4) for these vacancies. In both cases, the call-back ratio is statistically different from 1 if evaluated at the $1 \%$ significance level. Alternatively, for occupations with qualitative or no bottlenecks, call-back ratios are close to 1 . These outcomes are contradictory to what was expected. We turn back to this in the discussion section.

Finally, we breakdown the experimental data depending on whether the vacancy mentioned that some work experience was a plus point (row 6) and on whether it was explicitly stated that the job was open to both bachelor and master graduates (row 7). We expected a master degree to serve as a substitute for lack of work experience, but this is not what we find. On the contrary, having a master degree seems to be an advantage only when applying for vacancies that do not mention experience as a plus point. It is also remarkable that the invitation chances of bachelor applicants for these jobs (17.4\%) remain at least as high as for other jobs (16.9\%). Further, for jobs not explicitly mentioning being open to master graduates, we do not find any difference in positive reaction rates. Hence, even if it is not mentioned that the job is also open to master degrees, master degrees are still as likely to get a positive reaction as graduates with a bachelor degree. In the other case, when it is explicitly mentioned that the job is also open for masters, we do find that master graduates get more positive reactions for these jobs than bachelors. For these jobs, they are $70.6 \%$ (38.2\%) more likely to get a job invitation (positive reaction) than bachelor graduates. But also in this case, we find that the invitation chances of bachelor applicants for these jobs (17.5\%) remain at least as high as for other jobs (17.1\%).

\subsection{Multivariate Analysis}

To investigate more profoundly whether the relative preference for master graduates depends on the vacancy characteristics by which we broke down our research sample in the previous section, we end with a multivariate analysis. For this, we estimate a number of 
linear probability models with each application as observation unit and the call-back as outcome variable (coded 1 in the case of a positive call-back and 0 otherwise). Analyses are conducted both relying on the call-back sensu stricto (Table 3) and the call-back sensu lato (Table 4) definition. To account for both observed and unobserved differences between vacancies, vacancy level fixed effects are included.

\section{$<$ Table 3 about here $>$}

First, we estimate a regression including a dummy for the type of degree (normalised by subtracting the mean) and interaction effects between type of degree and the required domain (column 1). The results on type of degree corroborate with those of the bivariate analysis: on average, master graduates are 3.3 percentage points more likely to be invited for a job interview (Table 3) and 3.9 percentage points more likely to get any positive reaction (Table 4). But this relative advantage for master degrees differs significantly across educational domains. On the basis of both definitions of positive call-back, we find this relative advantage to be less strong for Business and Communication Science (i.e. the reference category) than for other domains.

Secondly, we look at whether the relative preference of master graduates depends on the type of firm and organisation (column 2 and 3). Therefore, we include interaction terms between the degree dummy and a number of sectoral dummies as well as with a dummy indicating the vacancy is for a job in a public organisation. While our bivariate analyses did not deliver significant call-back ratios for every sector and type of organisation, our multivariate analyses do not indicate that firm and organisation characteristics matter much. Only the interaction effect between the master degree dummy and the Finance, Insurance and Intellectual Services sector on the job invitation rate turns out to be statistically significant at the $10 \%$ level (Table 3, column 3); the returns on a master degree are somewhat higher in this sector.

\section{$<$ Table 4 about here $>$}

Next, we investigate whether recruitment behaviour depends on the bottleneck status of the occupation (column 4 and 5). In line with the conclusions of the bivariate analysis in the previous subsection, our multivariate analysis indicates that the relative preference for master graduates is stronger for quantitative bottleneck vacancies than for other vacancies; the difference in the job invitation rate (overall positive call-back rate) between masters and bachelors is 6.5 (12.4) percentage points larger for quantitative bottleneck vacancies than for vacancies without any type of bottleneck (column 4). Interestingly, the observed differences in the relative preference for masters across required educational domain largely disappear once the bottleneck status of the vacancy is accounted for (column 5). Hence, most of the observed differences across the educational domains seem to result from 
quantitative differences in labour market shortages. Only regarding the domain of Social Work and Pedagogy, we still do find the relative preference for master graduates to be stronger in comparison to the domain of Business and Communication Science.

Finally, we also include interaction terms between the degree dummy and dummies indicating that the vacancy mentioned work experience as a plus point or that the vacancy is open to both bachelor and master graduates (column 6 and 7). In line with the findings from the bivariate analysis, we do find the relative preference for master graduates to be much stronger when the vacancy explicitly mentions that the job is open to both bachelors and masters. This result holds both when relying on the sensu stricto and the sensu lato definition. Similarly, when relying on the sensu lato definition, we do find evidence on a stronger relative preference for master graduates in the case work experience is not mentioned as a plus point. These results remain intact if also the type of job and firm and the bottleneck status of the vacancy is accounted for (column 7).

\section{Discussion}

With this study, we aimed at investigating whether employers either prefer overqualified or adequately qualified applicants for vacant jobs. To this end, we conducted a randomised field experiment in the Belgian (Flemish) youth labour market in which we sent duos of fictitious applications (one for a bachelor graduate and one for a master graduate) to real job openings requiring a bachelor degree as minimum qualification. Along with reporting results for the overall sample, we looked at whether this preference for overqualified master graduates vis-à-vis adequately qualified bachelor graduates differs depending on the type of job and organisation and on whether vacancies are difficult to fill.

Our main results are as follows. First, relying on the overall sample, we found that the probability of receiving any positive reaction was about $11 \%$ higher for (overqualified) master applicants than for (adequately qualified) bachelor applicants. Moreover, masters were found to be about $19 \%$ more likely to be directly invited for a job interview. These differences in call-back proved to be statistically significant. Second, also at the level of most of the subsamples by vacancy characteristics, master graduates were found to have a higher call-back rate than bachelor graduates, but this difference was not always statistically significant. Alternatively, for none of the subsamples, we found statistically significant evidence for better job invitation chances for adequately qualified (bachelor) graduates. Third, additional multivariate analyses revealed that the relative preference for master graduates was particularly strong for occupations with quantitative bottlenecks, 
vacancies explicitly mentioning to be open to both bachelor and master graduates, vacancies not mentioning that some work experience may be a plus point and jobs requiring a degree in the domain of Social Work and Pedagogy.

These results have several important implications. First of all, they clearly reject that employers are reluctant to hire overqualified individuals. For many (but not all) jobs and segments, overqualified individuals are in front of the job queue as Thurow (1975) assumed in his job competition model. These findings are consistent with the conclusions of the stated choice experiments by van Beek et al. (1997) and Humburg and van der Velden (2015), who indicated that, in most labour markets, employers are either indifferent between (moderately) overqualified and adequately qualified applicants or even prefer (moderately) overqualified graduates. It thus seems that arguments contra hiring overqualified applicants, such as lower job satisfaction and higher wage costs, are usually (more than) compensated by arguments in favour of hiring them, such as higher trainability or ability. The latter conclusion also aligns with Kampelmann and Rycx (2012) and Mahy et al. (2015) who showed that overqualification has a strong positive impact on firm productivity. Part of the explanation may be that overqualified labour market entrants are preferred since they are slightly older and thus, perhaps, more mature. But even if so, it does not reject our conclusion that graduates may enhance their place in the job queue for first jobs by postponing labour market entry through obtaining an additional degree.

A second implication is related to the potential strength of eventual crowding out effects. On the one hand, the crowding out of adequately qualified workers is likely to be more pronounced when overqualified workers are in front of the job queue. On the other hand, we found this preference for overqualified workers to be particularly strong in jobs with high overall job invitation rates. Hence, since adequately qualified workers still have substantial chances to be invited for these jobs, crowding out effects are likely to be, at best, rather moderate. At least, this interpretation is consistent with the conclusions of van Ours and Ridder (1995) and those of Gautier et al. (2002), who investigated the crowding out hypothesis more directly and found only limited evidence for such effects.

Third, the abovementioned result regarding the difference between bottleneck and other vacancies refutes that overqualification is the result of employers being more selective when the relative supply of labour is high. This suggests that the often-observed countercyclicality of overqualification and overeducation rather results from an increase in job seekers' willingness to accept any type of jobs (cf. Dolado et al., 2009) or from changes in task assignments among existing workers (cf. Devereux, 2000) than from more selective recruitment policies. However, the question remains why employers facing quantitative bottlenecks are actually even more likely to invite overqualified master than adequately 
qualified bachelor graduates. One explanation for this finding may be that, to increase the pool of potential hires, these employers open their vacancies to undereducated job seekers by reducing the minimal qualification mentioned in the vacancy to a level below the one actually required for doing these jobs. Additional employer-sponsored training may then help reducing the skill deficits in case an undereducated workers has to be hired. However, for two main reasons, we do not expect this to be the dominant explanation. First of all, since it would still be preferable to hire adequately educated graduates, we would expect these employers to mention explicitly in the vacancy that the job is also open to master graduates. However, the correlation between quantitative bottleneck vacancies and vacancies mentioning the job is open to both bachelor and master graduates is close to zero in our sample. ${ }^{14}$ Secondly, we would expect employers to consider the selection of these undereducated individuals only as a last option, i.e. in the case little or no other applications are received. Our finding that the invitation rates of bachelor graduates for these jobs were still substantially higher than those for other jobs contradicts this. An alternative explanation for our finding of higher returns on a master degree in quantitative bottleneck occupations may be that these overqualified applicants are hoarded in view of eventual vacancies in the near future for related jobs with more responsibilities. As such, they anticipate to difficulties to fill these positions as well. But this is an interpretation that cannot be tested relying on our data and thus requires further investigation, for instance by tracking overqualified workers over time.

A fourth implication is related to the role of the sector of employment and the type of organisation. Overall, we did not find much evidence on systematic differences in recruitment behaviour with respect to adequately qualified and overqualified job candidates depending on these variables. In line with the claims of van der Meer and Wielers (1996), we found some indications that organisations within sectors with difficulties to measure product quality, such as the Finance, Insurance and Intellectual Services sector, are more likely to prefer overqualified job seekers. However, this finding was only barely statistically significant and did only show up relying on our sensu stricto definition of positive call-back. One explanation for this lack of evidence may be that eventual structural differences in recruitment behaviour across sectors already translate in differences in the minimal requirements that are mentioned in the vacancies. These structural differences across sectors may thus translate in differences in overeducation but not in overqualification. ${ }^{15}$

\footnotetext{
${ }^{14}$ This correlation is equal to 0.065 and not statistically significant at the $10 \%$ level.

${ }^{15}$ Note that, in the case of the Finance, Insurance and Intellectual Services sector, one may discuss whether these individuals are truly overeducated from a private point of view given the high profits and wages in this sector (e.g., Du Caju et al., 2011). Even if their skills are not fully utilised, the increased value of the marginal product resulting from hiring these workers instead of lower educated ones may well exceed the costs of their investments in additional years of education.
} 
Conversely, our results suggest substantial differences in selection behaviour within sectors and across employers, with employers having a relative preference for master graduates explicitly mentioning that the vacancy is open to both bachelor and master graduates. This aligns with the conclusions of Humburg and van der Velden (2015), who also found substantial heterogeneity in recruitment behaviour among similar types of employers. It thus seems that there are significant differences in the opinions of recruiters about the extent to which a surplus of qualifications is beneficial to the firm, perhaps because recruiters have different past experiences in this respect.

One last implication is related to the role of formal education as a substitute for other types of human capital. It is often argued that overeducation and overqualification are the consequence of a lack of work experience and more practical skills (Sicherman and Galor, 1990). While our analysis focussed on vacancies for which experience was not a necessary prerequisite to be selected, it was often mentioned in the vacancy that some work experience was considered to be a plus. But conversely to expectations, we did not find overqualified master graduates to be preferred to adequately qualified bachelor graduates for these jobs. Similarly, we did not find selection chances to differ between both groups for vacancies with so-called qualitative bottlenecks, i.e. when vacancies are difficult to fill because of a lack of candidates with suitable skills. It thus seems that employers do not consider the additional skills obtained at university to be good substitutes for the other more practical skills that are required for these jobs. Of course, one may expect this conclusion to differ for overqualified workers with a vocational degree as surplus education. But to investigate this, additional research focussing on more intermediate levels of qualifications would be required.

\section{Conclusion}

To conclude, our analysis clearly indicates that being moderately overqualified for a vacant job should not be detrimental for being selected and, for some jobs, may even deliver an advantage. But even if so, the eventual crowding out of adequately qualified bachelor graduates as a consequence of this selection policy is unlikely to be large since this advantage for overqualified master graduates is in particular observed for jobs with high overall probabilities to be selected. This conclusion adds to those of a few other studies on this issue finding only limited evidence on crowding out. Of course, it should be stressed that our results only apply to the upper skill segments of the labour market. As the evidence on labour market polarisation shows (Goos et al., 2009), the context for the medium and low-skilled segments is largely different. Hence, further research is required to assess 
whether our results can be generalised to these segments as well. Finally, we only focussed on rather moderately overqualified graduates. Research relying on stated choice experiments already suggested results to differ for more severely overqualified individuals (Humburg and van der Velden, 2015), but also regarding this issue additional research relying on experiments in the field is advised.

\section{References}

Baert, S., Cockx, B., Gheyle, N., and Vandamme, C. (2015). Is There Less Discrimination in Occupations Where Recruitment Is Difficult? ILR Review, 68, 467-500.

Baert, S., and Verhaest, D. (2014). Unemployment or Overeducation: Which is a Worse Signal to Employers? IZA Discussion Papers, No. 8312, Bonn: Institute for the Study of Labor, 25p.

Bertrand, M., and Mullainathan, S. (2004). Are Emily and Greg more employable than Lakisha and Jamal? A field experiment on labor market discrimination. American Economic Review, 94, 991-1013.

Bozeman, B. (1987). All organizations are public: Bridging public and private organizational theories. San Francisco: Jossey-Bass.

Büttner, T., Jacobebbinghaus, P., and Ludsteck, J. (2010). Occupational Upgrading and the Business Cycle in West Germany. Economics: The Open-Access, Open-Assessment E-Journal, 4, 2010-10.

Cédiey, E., Foroni, F., and Garner, H. (2008). Discrimination à l'embauche fondée sur l'origine à l'encontre des jeunes français(e)s peu qualifié(e)s. Dares Premières Infos Premières Synthèses, 06.3.

Devereux, P. (2000). Task assignment over the business cycle. Journal of Labor Economics, 18, 98-124.

Devereux, P. (2002). Occupational upgrading and the business cycle. Labour, 16, 423452.

Devereux, P. (2004). Cyclical quality adjustment in the labor market. Southern Economic Journal, 70, 600-615.

Dolado, J., Jansen, M., and Jimeno, J. (2009). On-the-job search in a matching model with heterogeneous jobs and workers. Economic Journal, 119, 200-228.

Dolton, P., and Silles, M. (2003). The determinants and consequences of graduate 
overeducation. In F. Büchel, A. de Grip and A. Mertens (eds), Overeducation in Europe, Current Issues in Theory and Policy. Cheltenham: Edward Elgar.

Dolton, P., and Vignoles, A. (2000). The incidence and effects of overeducation in the U.K. graduate labour market. Economics of Education Review, 19, 179-298.

Drydakis, N. (2015). University Attended and Graduates' Labor Market Prospects: A Field Study for Britain. Mimeo.

Du Caju, P., Rycx, F., and Tojerow, I. (2011). Inter-industry wage differentials: how much does rent sharing matter? Manchester School, 79, 691-717.

Eriksson, S., and Rooth, D. (2014). Do employers use unemployment as a sorting criterion when hiring? Evidence from a field experiment. American Economic Review, 104, 1014-1039.

Gautier, P., van den Berg, G., van Ours, J., and Ridder, G. (2002). Worker turnover at the firm level and crowding out of lower educated workers. European Economic Review, $46,53-538$.

Gesthuizen, M., and Wolbers, M. (2010). Employment transitions in the Netherlands, 1980-2004: Are low educated men subject to structural or cyclical crowding out? Research in Social Stratification and Mobility, 28, 437-451.

Goos, M., Manning, A., and Salomons, A. (2009). The polarization of the European labor market. American Economic Review, 99, 58-63.

Gregg, P. (2001). The Impact of Youth Unemployment on Adult Unemployment in the NCDS. Economic Journal, 111, 626-653.

Hainmueller, J., Hangartner, D., and Yamamoto, T. (2015). Validating vignette and conjoint survey experiments against real-world behavior. Proceedings of the National Academy of Sciences, 112, 2395-2400.

Hall, R. (1974). The process of inflation in the labor market. Brooking Papers on Economic Activity, 2, 343-393.

Hartog, J. (2000). Over-education and earnings: where are we, where should we go? Economics of Education Review, 19, 131-147.

Heckman, J.J., and Siegelman, C. (1993). The Urban Institute Audit Studies: Their Methods and Findings. Washington DC: Urban Institute.

Hershbein, B., and Kahn, L. (2015). Is College the New High School? Evidence from Vacancy Postings. Paper presented at the Fourth World SOLE/EALE Conference, Montreal, 26-28 June 2015. 
Humburg, M., and van der Velden, R. (2015). Skills and the graduate recruitment process: Evidence from two discrete choice experiments. Economics of Education Review, $49,24-41$.

Kampelmann, S., and Rycx, F. (2012). The impact of educational mismatch on firm productivity: Evidence from linked panel data. Economics of Education Review, 31, 918931.

Korpi, T., and Tåhlin, M. (2009). Educational mismatch, wages, and wage growth: Overeducation in Sweden, 1974-2000. Labour Economics, 16, 183-193.

Kroft, K., Lange, F., and Notowidigdo, M. (2013). Duration dependence and labor market conditions: evidence from a field experiment. Quarterly Journal of Economics, 128, $1123-1167$.

Mahy, B., Rycx, F., and Vermeylen, G. (2015). Educational mismatch and firm productivity: do skills, technology and uncertainty matter? De Economist, 163, 233-262.

McCormick, B. (1990). A Theory of Signalling During Job Search, Employment Efficiency, and "Stigmatised" Jobs. Review of Economic Studies, 57, 299-313.

McGuinness, S. (2006). Overeducation in the labour market. Journal of Economic Surveys, 20, 387-418.

Ministerie van Onderwijs en Vorming (2015). Hoger Onderwijs in Cijfers - Aantal inschrijvingen op 31 Oktober 2014 Academiejaar 2014-2015. Brussels: Vlaamse Overheid.

Mroz, T., and Savage, T. (2006). The Long-Term Effects of Youth Unemployment. Journal of Human Resources, 41, 259-293.

Neill, H.R., Cummings, R.G., Ganderton, P.T., Harrison, G.W., and McGuckin, T. (1994). Hypothetical surveys and real economic commitments. Land Economics, 70, 145154.

Nunley, J.M., Pugh, A., Romero, N., and Seals, R.A. (Forthcoming). College Major, Internship Experience, and Employment Opportunities: Estimates from a Résumé Audit. Labour Economics. DOI: 10.1016/j.labeco.2015.11.002.

Okun, A. (1981). Prices and Quantities: A Macroeconomic Analysis. Washington D.C.: Brookings Institution.

Pager, D. (2007). The use of field experiments for studies of employment discrimination: Contributions, critiques, and directions for the future. Annals of the American Academy of Political and Social Science, 609, 104-133.

Pollman-Schult, M. (2005). Crowding-out of Unskilled Workers in the Business Cycle: 
Evidence from West Germany. European Sociological Review, 21, 467-480.

Reder, M. (1955). The theory of occupational wage differentials. American Economic Review, 45, 833-852.

Riach, P.A., and Rich, J. (2002). Field Experiments of Discrimination in the Market Place. Economic Journal, 112, 480-518.

Riach, P.A., and Rich, J. (2004). Deceptive Field Experiments of Discrimination: Are They Ethical? Kyklos, 57, 457-470.

Robst, J. (1995). Career Mobility, Job Match and Overeducation. Eastern Economic Journal, 21, 539-550.

Rubb, S. (2003). Overeducation in the labor market: a comment and re-analysis of a meta-analysis. Economics of Education Review, 22, 621-629.

Sicherman, N., and Galor, O. (1990). A theory of career mobility. Journal of Political Economy, 98, 169-192.

Spence, M. (1973). Job market signaling. Quarterly Journal of Economics, 87, 355-374.

Teulings, C., and Koopmanschap, M. (1989). An econometric model of crowding out of lower education levels. European Economic Review, 33, 1653-1664.

Thurow, L. (1975). Generating Inequality, New York: Basic Books.

Tsang, M., Rumberger, R., and Levin, H. (1991). The Impact of Surplus Schooling on Worker Productivity. Industrial Relations, 30, 209-228.

van Beek, K., Koopmans, C., and van Praag, B. (1997). Shopping at the labour market: A real tale of fiction. European Economic Review, 41, 295-317.

van der Meer, P., and Wielers, R. (1996). Educational credentials and trust in the labor market. Kyklos, 49, 29-46.

van Ours, J., and Ridder, G. (1995). Job matching and job competition: are lower educated workers at the back of the job queues? European Economic Review, 39, 17171731.

VDAB (2015). Werkzoekende schoolverlaters in Vlaanderen, 28ste studie - editie 2015. Brussels: VDAB.

Verhaest, D., and Omey, E. (2006). Measuring the incidence of over- and undereducation. Quality \& Quantity, 40, 783-803.

Verhaest, D., and Omey, E. (2009). Objective over-education and worker well-being: a shadow price approach. Journal of Economic Psychology, 30, 469-481. 


\section{Appendix A: Additional Tables}

$<$ Table A1 about here $>$

$<$ Table A2 about here $>$

$<$ Table A3 about here $>$ 
Table 1. Call-Back Sensu Stricto: Positive call-back rates and ratios

\begin{tabular}{|c|c|c|c|c|}
\hline & $(1)$ & $(2)$ & $(3)$ & $(4)$ \\
\hline & $\begin{array}{l}\text { Positive call-back } \\
\text { rate overall }\end{array}$ & $\begin{array}{l}\text { Positive call-back } \\
\text { rate master }\end{array}$ & $\begin{array}{l}\text { Positive call-back } \\
\text { rate bachelor }\end{array}$ & $\begin{array}{l}\text { Call-back ratio } \\
\text { master/bachelor }\end{array}$ \\
\hline 1. All vacancies & 0.188 & 0.205 & 0.172 & $1.193^{* *}$ \\
\hline \multicolumn{5}{|l|}{ 2. By required educational domain } \\
\hline Business and Communication Science & 0.102 & 0.092 & 0.112 & 0.824 \\
\hline Industrial Science and Engineering & 0.250 & 0.278 & 0.222 & $1.250^{*}$ \\
\hline Computer Science and Engineering & 0.284 & 0.328 & 0.241 & $1.357^{*}$ \\
\hline Health Care & 0.292 & 0.317 & 0.267 & 1.188 \\
\hline Social Work and Pedagogy & 0.076 & 0.098 & 0.054 & 1.800 \\
\hline \multicolumn{5}{|l|}{ 3. By sector of activity } \\
\hline Manufacturing, Energy and Construction & 0.144 & 0.169 & 0.119 & $1.429^{*}$ \\
\hline Wholesale, Retail, Catering, Transport and Communication & 0.190 & 0.195 & 0.186 & 1.048 \\
\hline Finance, Insurance and Intellectual Services & 0.168 & 0.192 & 0.143 & $1.346^{* *}$ \\
\hline Public Administration, Education, Culture and Membership Organisations & 0.134 & 0.143 & 0.125 & 1.143 \\
\hline Health Care and Social Work Activities & 0.232 & 0.255 & 0.208 & $1.226^{*}$ \\
\hline \multicolumn{5}{|l|}{ 4. By type of organisation } \\
\hline Private & 0.185 & 0.204 & 0.166 & $1.228^{* *}$ \\
\hline Public & 0.195 & 0.207 & 0.183 & 1.129 \\
\hline \multicolumn{5}{|l|}{ 5. By bottleneck character of the vacancy } \\
\hline Quantitative bottleneck & 0.289 & 0.325 & 0.254 & $1.283^{* * *}$ \\
\hline Qualitative bottleneck & 0.108 & 0.111 & 0.104 & 1.067 \\
\hline No bottleneck & 0.129 & 0.132 & 0.126 & 1.050 \\
\hline \multicolumn{5}{|l|}{ 6. By whether vacancy mentions some work experience is plus point } \\
\hline Not mentioned & 0.195 & 0.215 & 0.174 & $1.235^{* *}$ \\
\hline Mentioned & 0.180 & 0.192 & 0.169 & 1.135 \\
\hline \multicolumn{5}{|l|}{ 7. By whether vacancy mentions job is open to both bachelors and masters } \\
\hline Not mentioned & 0.177 & 0.183 & 0.171 & 1.070 \\
\hline Mentioned & 0.237 & 0.299 & 0.175 & $1.706^{* * *}$ \\
\hline
\end{tabular}

(* $(* *)((* * *))$ indicates the ratio is significantly different from 1 at the $10 \%(5 \%)((1 \%))$ significance level. 
Table 2. Call-Back Sensu Lato: Positive call-back rates and ratios

\begin{tabular}{|c|c|c|c|c|}
\hline & $(1)$ & $(2)$ & (3) & $(4)$ \\
\hline & $\begin{array}{l}\text { Positive call-back } \\
\text { rate overall }\end{array}$ & $\begin{array}{l}\text { Positive call-back } \\
\text { rate master }\end{array}$ & $\begin{array}{l}\text { Positive call-back } \\
\text { rate bachelor }\end{array}$ & $\begin{array}{l}\text { Call-back ratio } \\
\text { master/bachelor }\end{array}$ \\
\hline 1. All vacancies & 0.363 & 0.383 & 0.344 & $1.114^{* *}$ \\
\hline \multicolumn{5}{|l|}{ 2. By required educational domain } \\
\hline Business and Communication Science & 0.306 & 0.289 & 0.322 & 0.898 \\
\hline Industrial Science and Engineering & 0.456 & 0.489 & 0.422 & 1.158 \\
\hline Computer Science and Engineering & 0.500 & 0.552 & 0.448 & $1.231^{*}$ \\
\hline Health Care & 0.446 & 0.483 & 0.408 & $1.184^{* *}$ \\
\hline Social Work and Pedagogy & 0.174 & 0.196 & 0.152 & $1.286^{* *}$ \\
\hline \multicolumn{5}{|l|}{ 3. By sector of activity } \\
\hline Manufacturing, Energy and Construction & 0.305 & 0.322 & 0.288 & 1.118 \\
\hline Wholesale, Retail, Catering, Transport and Communication & 0.385 & 0.398 & 0.372 & 1.071 \\
\hline Finance, Insurance and Intellectual Services & 0.393 & 0.412 & 0.374 & 1.103 \\
\hline Public Administration, Education, Culture and Membership Organisations & 0.330 & 0.339 & 0.321 & 1.056 \\
\hline Health Care and Social Work Activities & 0.332 & 0.369 & 0.295 & $1.250^{* *}$ \\
\hline \multicolumn{5}{|l|}{ 4. By type of organisation } \\
\hline Private & 0.367 & 0.385 & 0.350 & 1.100 \\
\hline Public & 0.355 & 0.379 & 0.331 & $1.143^{*}$ \\
\hline \multicolumn{5}{|l|}{ 5. By bottleneck character of the vacancy } \\
\hline Quantitative bottleneck & 0.498 & 0.550 & 0.445 & $1.237^{* * *}$ \\
\hline Qualitative bottleneck & 0.240 & 0.243 & 0.236 & 1.029 \\
\hline No bottleneck & 0.299 & 0.289 & 0.308 & 0.939 \\
\hline \multicolumn{5}{|l|}{ 6. By whether vacancy mentions some work experience is plus point } \\
\hline Not mentioned & 0.401 & 0.433 & 0.369 & $1.176^{* * *}$ \\
\hline Mentioned & 0.313 & 0.315 & 0.311 & 1.015 \\
\hline \multicolumn{5}{|l|}{ 7. By whether vacancy mentions job is open to both bachelors and masters } \\
\hline Not mentioned & 0.351 & 0.359 & 0.342 & 1.049 \\
\hline Mentioned & 0.418 & 0.485 & 0.351 & $1.382^{* * *}$ \\
\hline
\end{tabular}

$\left.*^{* *}\right)((* * *))$ indicates the ratio is significantly different from 1 at the $10 \%(5 \%)((1 \%))$ significance level. 
Table 3. Call-back Sensu Stricto: Linear probability estimates

\begin{tabular}{|c|c|c|c|c|c|c|c|}
\hline & $(1)$ & $(2)$ & $(3)$ & $(4)$ & $(5)$ & $(6)$ & (7) \\
\hline \multirow{2}{*}{ Master (normalised) } & $0.033^{* *}$ & $0.033^{* *}$ & $0.033^{* *}$ & $0.033^{* *}$ & $0.033^{* *}$ & $0.033^{* *}$ & $0.033^{* *}$ \\
\hline & $(0.014)$ & $(0.014)$ & $(0.014)$ & $(0.014)$ & $(0.014)$ & $(0.014)$ & $(0.014)$ \\
\hline \multirow{2}{*}{ Master x Industrial Science and Engineering educational program } & $0.075^{*}$ & . & $0.072^{*}$ & - & 0.025 & . & 0.001 \\
\hline & $(0.042)$ & - & $(0.043)$ & - & $(0.057)$ & - & $(0.056)$ \\
\hline \multirow{2}{*}{ Master x Computer Science and Engineering educational program } & $0.106^{*}$ & 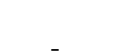 & $0.118^{* *}$ & & 0.065 & & 0.036 \\
\hline & $(0.057)$ & - & $(0.057)$ & - & $(0.077)$ & - & $(0.077)$ \\
\hline \multirow{2}{*}{ Master x Health Care educational program } & $0.070^{*}$ & 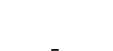 & $0.108^{* *}$ & - & 0.080 & 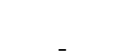 & 0.068 \\
\hline & $(0.042)$ & & $(0.053)$ & & $(0.059)$ & & $(0.058)$ \\
\hline \multirow{2}{*}{ Master x Social Work and Pedagogy educational program } & $0.063^{*}$ & & $0.106^{* *}$ & & $0.110^{* *}$ & & $0.102^{* *}$ \\
\hline & $(0.037)$ & - & $(0.048)$ & - & $(0.048)$ & - & $(0.046)$ \\
\hline \multirow{2}{*}{ Master x Manufacturing, Energy and Construction sector } & \multirow{2}{*}{ - } & 0.045 & 0.049 & & 0.046 & & 0.047 \\
\hline & & $(0.041)$ & $(0.043)$ & - & $(0.043)$ & - & $(0.042)$ \\
\hline \multirow{2}{*}{ Master x Finance, Insurance and Intellectual Services sector } & \multirow{2}{*}{ - } & 0.050 & $0.066^{*}$ & & 0.067 & & $0.073^{*}$ \\
\hline & & $(0.038)$ & $(0.040)$ & - & $(0.041)$ & - & $(0.040)$ \\
\hline \multirow{2}{*}{ Master x Health Care and Social Work activities sector } & \multirow{2}{*}{ - } & 0.060 & 0.033 & & 0.025 & & 0.038 \\
\hline & & $(0.041)$ & $(0.044)$ & - & $(0.043)$ & - & $(0.043)$ \\
\hline \multirow{2}{*}{ Master x Public organisation } & \multirow{2}{*}{ - } & -0.015 & -0.036 & \multirow{2}{*}{-} & -0.042 & & -0.038 \\
\hline & & $(0.037)$ & $(0.039)$ & & $(0.040)$ & - & $(0.039)$ \\
\hline \multirow{2}{*}{ Master x Quantitative bottleneck vacancy } & \multirow{2}{*}{ - } & \multirow{2}{*}{ - } & & $0.065^{*}$ & 0.061 & \multirow{2}{*}{ - } & 0.071 \\
\hline & & & & $(0.034)$ & $(0.049)$ & & $(0.049)$ \\
\hline \multirow{2}{*}{ Master x Qualitative bottleneck vacancy } & \multirow{2}{*}{ - } & \multirow{2}{*}{ - } & \multirow{2}{*}{ - } & 0.001 & 0.011 & \multirow{2}{*}{ - } & 0.022 \\
\hline & & & & $(0.034)$ & $(0.037)$ & & $(0.036)$ \\
\hline \multirow{2}{*}{ Master x Vacancy mentions some work experience is plus point } & \multirow{2}{*}{ - } & \multirow{2}{*}{-} & \multirow{2}{*}{-} & \multirow{2}{*}{ - } & \multirow{2}{*}{-} & -0.022 & -0.020 \\
\hline & & & & & & $(0.029)$ & $(0.029)$ \\
\hline \multirow{2}{*}{ Master x Vacancy mentions job is open to both bachelors and masters } & \multirow{2}{*}{-} & \multirow{2}{*}{ - } & - & - & & $0.113^{* * *}$ & $0.110^{* * *}$ \\
\hline & & & & & & $(0.037)$ & $(0.036)$ \\
\hline
\end{tabular}

All models also include a constant term and vacancy fixed effects. Robust standard errors are between parentheses. ${ }^{*}(* *)((* * *))$ indicates significance at the $10 \%(5 \%)((1 \%))$ significance level. Number of observations $=1024$. 
Table 4. Call-back Sensu Lato: Linear probability estimates

\begin{tabular}{|c|c|c|c|c|c|c|c|}
\hline & $(1)$ & $(2)$ & $(3)$ & $(4)$ & $(5)$ & $(6)$ & $(7)$ \\
\hline \multirow{2}{*}{ Master (normalised) } & $0.039^{* *}$ & $0.039^{* *}$ & $0.039^{* *}$ & $0.039^{* *}$ & $0.039^{* *}$ & $0.039^{* *}$ & $0.039^{* *}$ \\
\hline & $(0.016)$ & $(0.016)$ & $(0.016)$ & $(0.016)$ & $(0.016)$ & $(0.016)$ & $(0.016)$ \\
\hline \multirow{2}{*}{ Master x Industrial Science and Engineering educational program } & $0.100^{*}$ & & $0.103^{*}$ & & -0.006 & & -0.034 \\
\hline & $(0.052)$ & - & $(0.056)$ & - & $(0.071)$ & - & $(0.071)$ \\
\hline \multirow{2}{*}{ Master x Computer Science and Engineering educational program } & $0.136^{* *}$ & - & $0.143^{* *}$ & & 0.022 & & -0.011 \\
\hline & $(0.062)$ & - & $(0.063)$ & - & $(0.088)$ & - & $(0.088)$ \\
\hline Master x Health Care educational program & $0.108^{* *}$ & _ & $0.106^{*}$ & - & 0.044 & - & 0.030 \\
\hline \multirow{2}{*}{ Master x Social Work and Pedagogy educational program } & $0.076^{* *}$ & & $0.087^{*}$ & & $0.097^{* *}$ & & $0.089^{* *}$ \\
\hline & $(0.038)$ & - & $(0.045)$ & - & $(0.046)$ & - & $(0.044)$ \\
\hline \multirow{2}{*}{ Master x Manufacturing, Energy and Construction sector } & \multirow{2}{*}{-} & 0.022 & 0.014 & & 0.009 & & 0.011 \\
\hline & & $(0.041)$ & $(0.047)$ & - & $(0.048)$ & - & $(0.047)$ \\
\hline \multirow{2}{*}{ Master x Finance, Insurance and Intellectual Services sector } & \multirow{2}{*}{-} & 0.031 & 0.044 & _- & 0.048 & & 0.060 \\
\hline & & $(0.045)$ & $(0.046)$ & - & $(0.046)$ & - & $(0.046)$ \\
\hline Master x Health Care and Social Work activities sector & - & 0.071 & 0.051 & & 0.034 & & 0.052 \\
\hline \multirow{2}{*}{ Master x Public organisation } & \multirow{2}{*}{ - } & -0.006 & -0.020 & \multirow{2}{*}{ - } & -0.034 & \multirow{2}{*}{ - } & -0.030 \\
\hline & & $(0.041)$ & $(0.043)$ & & $(0.044)$ & & $(0.043)$ \\
\hline \multirow{2}{*}{ Master x Quantitative bottleneck vacancy } & \multirow{2}{*}{-} & \multirow{2}{*}{-} & \multirow{2}{*}{ - } & $0.124^{* * *}$ & $0.143^{* *}$ & \multirow{2}{*}{-} & $0.150^{* *}$ \\
\hline & & & & $(0.039)$ & $(0.062)$ & & $(0.062)$ \\
\hline \multirow{2}{*}{ Master x Qualitative bottleneck vacancy } & \multirow{2}{*}{-} & \multirow{2}{*}{-} & \multirow{2}{*}{ - } & 0.026 & 0.033 & \multirow{2}{*}{ - } & 0.046 \\
\hline & & & & $(0.040)$ & $(0.041)$ & & $(0.041)$ \\
\hline \multirow{2}{*}{ Master x Vacancy mentions some work experience is plus point } & \multirow{2}{*}{-} & \multirow{2}{*}{ - } & \multirow{2}{*}{-} & \multirow{2}{*}{ - } & \multirow{2}{*}{-} & $-0.065^{* *}$ & $-0.054^{*}$ \\
\hline & & & & & & $(0.033)$ & $(0.033)$ \\
\hline \multirow{2}{*}{ Master x Vacancy mentions job is open to both bachelors and masters } & - & - & - & - & - & $0.121^{* * *}$ & $0.125^{* * *}$ \\
\hline & & - & & - & - & $(0.046)$ & $(0.046)$ \\
\hline
\end{tabular}

All models also include a constant term and vacancy fixed effects. Robust standard errors are between parentheses. $*(* *)((* * *))$ indicates significance at the $10 \%(5 \%)((1 \%))$ significance level. Number of observations $=1024$. 
Table A1. Selected Bachelor and Master Programs

\begin{tabular}{|c|c|c|}
\hline Educational domain & Bachelor program & Linked master program \\
\hline \multirow[t]{8}{*}{ Business and Communication Science } & Business Management: Accounting and Taxation & Business Administration: Accounting and Taxation \\
\hline & Business Management: Finance and Insurance & Business Administration: Finance and Risk Management \\
\hline & Business Management: International Business & Business Administration: Strategic Management \\
\hline & Business Management: SME Management & Business Administration: Strategic Management \\
\hline & Business Management: Logistics Management & Business Administration: Strategic Management \\
\hline & Business Management: Marketing & Business Administration: Marketing Management \\
\hline & Communication Management: Commercial Communication & Communication Science: Communication Management \\
\hline & Communication Management: Public Relations & Communication Science: Communication Management \\
\hline \multirow[t]{5}{*}{ Industrial Science and Engineering } & Chemistry: Biochemistry & Industrial Sciences: Biochemistry \\
\hline & Chemistry: Chemistry & Industrial Sciences: Chemistry \\
\hline & Electromechanics: Automation & Industrial Sciences: Electromechanics \\
\hline & Electromechanics: Electromechanics & Industrial Sciences: Electromechanics \\
\hline & Electromechanics: Climate Control & Industrial Sciences: Electromechanics \\
\hline Computer Science and Engineering & Applied Computer Science & Industrial Sciences: Computer Science \\
\hline \multirow[t]{7}{*}{ Health Care } & Nursing: Geriatrics & Nursing and Midwifery \\
\hline & Nursing: child nursing & Nursing and Midwifery \\
\hline & Nursing: psychiatry & Nursing and Midwifery \\
\hline & Nursing: Social nursing & Nursing and Midwifery \\
\hline & Nursing: Hospital nursing & Nursing and Midwifery \\
\hline & Speech-language pathology and Audiology: Logopaedics & Speech Language and Hearing Sciences: Logopaedics \\
\hline & Speech-language pathology and Audiology: Audiology & Speech Language and Hearing Sciences: Audiology \\
\hline \multirow[t]{5}{*}{ Social Work and Pedagogy } & Social Work: Social Work & Social Work and Social Welfare Studies \\
\hline & Social Work: Social Advice and Legal Services & Social Work and Social Welfare Studies \\
\hline & Social Work: Human Resources & Social Work and Social Welfare Studies \\
\hline & Social Work: Socio-Cultural Work & Social Work and Social Welfare Studies \\
\hline & Orthopedagogics & Educational Sciences: Orthopedagogics \\
\hline
\end{tabular}




\section{Table A2. Call-Back Sensu Stricto: Frequencies}

\begin{tabular}{|c|c|c|c|c|c|}
\hline & $(1)$ & $(2)$ & $(3)$ & $(4)$ & $(5)$ \\
\hline & \multirow{2}{*}{$\begin{array}{c}\text { Overall number } \\
\text { of selected job } \\
\text { openings }\end{array}$} & \multicolumn{4}{|c|}{ Number of job openings by call-back sensu stricto } \\
\hline & & No invitation & $\begin{array}{l}\text { Invitation for } \\
\text { both }\end{array}$ & $\begin{array}{l}\text { Only invitation } \\
\text { for master }\end{array}$ & $\begin{array}{l}\text { Only invitation } \\
\text { for bachelor }\end{array}$ \\
\hline 1. All vacancies & 512 & 388 & 69 & 36 & 19 \\
\hline \multicolumn{6}{|l|}{ 2. By required educational domain } \\
\hline Business and Communication Science & 152 & 129 & 8 & 6 & 9 \\
\hline Industrial Science and Engineering & 90 & 63 & 18 & 7 & 2 \\
\hline Computer Science and Engineering & 58 & 37 & 12 & 7 & 2 \\
\hline Health Care & 120 & 77 & 27 & 11 & 5 \\
\hline Social Work and Pedagogy & 92 & 82 & 4 & 5 & 1 \\
\hline \multicolumn{6}{|l|}{ 3. By sector of activity } \\
\hline Manufacturing, Energy and Construction & 59 & 49 & 7 & 3 & 0 \\
\hline Wholesale, Retail, Catering, Transport and Communication & 113 & 85 & 15 & 7 & 6 \\
\hline Finance, Insurance and Intellectual Services & 182 & 141 & 20 & 15 & 6 \\
\hline Public Administration, Education, Culture and Membership Organisations & 56 & 46 & 5 & 3 & 2 \\
\hline Health Care and Social Work Activities & 149 & 106 & 26 & 12 & 5 \\
\hline \multicolumn{6}{|l|}{ 4. By type of organisation } \\
\hline Private & 343 & 260 & 44 & 26 & 13 \\
\hline Public & 169 & 128 & 25 & 10 & 6 \\
\hline \multicolumn{6}{|l|}{ 5. By bottleneck character of the vacancy } \\
\hline Quantitative bottleneck & 209 & 134 & 46 & 22 & 7 \\
\hline Qualitative bottleneck & 144 & 122 & 9 & 7 & 6 \\
\hline No bottleneck & 159 & 132 & 14 & 7 & 6 \\
\hline \multicolumn{6}{|l|}{ 6. By whether vacancy mentions some work experience is plus point } \\
\hline Not mentioned & 293 & 220 & 41 & 22 & 10 \\
\hline Mentioned & 219 & 168 & 28 & 14 & 9 \\
\hline \multicolumn{6}{|l|}{ 7. By whether vacancy mentions job is open to both bachelors and masters } \\
\hline Not mentioned & 415 & 320 & 52 & 24 & 19 \\
\hline Mentioned & 97 & 68 & 17 & 12 & 0 \\
\hline
\end{tabular}


Table A3. Call-Back Sensu Lato: Frequencies

\begin{tabular}{|c|c|c|c|c|c|}
\hline & $(1)$ & $(2)$ & $(3)$ & $(4)$ & $(5)$ \\
\hline & \multirow{2}{*}{$\begin{array}{c}\text { Overall number } \\
\text { of selected job } \\
\text { openings }\end{array}$} & \multicolumn{4}{|c|}{ Number of job openings by call-back sensu lato } \\
\hline & & No invitation & $\begin{array}{l}\text { Invitation for } \\
\text { both }\end{array}$ & No invitation & $\begin{array}{l}\text { Only invitation } \\
\text { for bachelor }\end{array}$ \\
\hline 1. All vacancies & 512 & 290 & 150 & 46 & 26 \\
\hline \multicolumn{6}{|l|}{ 2. By required educational domain } \\
\hline Business and Communication Science & 152 & 94 & 35 & 9 & 14 \\
\hline Industrial Science and Engineering & 90 & 42 & 34 & 10 & 4 \\
\hline Computer Science and Engineering & 58 & 24 & 24 & 8 & 2 \\
\hline Health Care & 120 & 56 & 43 & 15 & 6 \\
\hline Social Work and Pedagogy & 92 & 74 & 14 & 4 & 0 \\
\hline \multicolumn{6}{|l|}{ 3. By sector of activity } \\
\hline Manufacturing, Energy and Construction & 59 & 40 & 17 & 2 & 0 \\
\hline Wholesale, Retail, Catering, Transport and Communication & 113 & 61 & 35 & 10 & 7 \\
\hline Finance, Insurance and Intellectual Services & 182 & 95 & 56 & 19 & 12 \\
\hline Public Administration, Education, Culture and Membership Organisations & 56 & 35 & 16 & 3 & 2 \\
\hline Health Care and Social Work Activities & 149 & 89 & 39 & 16 & 5 \\
\hline \multicolumn{6}{|l|}{ 4. By type of organisation } \\
\hline Private & 343 & 190 & 99 & 33 & 21 \\
\hline Public & 169 & 100 & 51 & 13 & 5 \\
\hline \multicolumn{6}{|l|}{ 5. By bottleneck character of the vacancy } \\
\hline Quantitative bottleneck & 209 & 87 & 86 & 29 & 7 \\
\hline Qualitative bottleneck & 144 & 101 & 26 & 9 & 8 \\
\hline No bottleneck & 159 & 102 & 38 & 8 & 11 \\
\hline \multicolumn{6}{|l|}{ 6. By whether vacancy mentions some work experience is plus point } \\
\hline Not mentioned & 293 & 154 & 96 & 31 & 12 \\
\hline Mentioned & 219 & 136 & 54 & 15 & 14 \\
\hline \multicolumn{6}{|l|}{ 7. By whether vacancy mentions job is open to both bachelors and masters } \\
\hline Not mentioned & 415 & 243 & 119 & 30 & 23 \\
\hline Mentioned & 97 & 47 & 31 & 16 & 3 \\
\hline
\end{tabular}

